\title{
Survive Another Day: Using Changes in the Composition of Investments to Measure the Cost of Credit Constraints
}

\section{Citation}

Garicano, Luis, and Claudia Steinwender. 2016. "Survive Another Day: Using Changes in the Composition of Investments to Measure the Cost of Credit Constraints." Review of Economics and Statistics 98 (5) (December): 913-924. doi:10.1162/rest_a_00566.

\section{Published Version}

10.1162/rest_a_00566

\section{Permanent link}

http://nrs. harvard.edu/urn-3:HUL.InstRepos:33785680

\section{Terms of Use}

This article was downloaded from Harvard University's DASH repository, and is made available under the terms and conditions applicable to Other Posted Material, as set forth at http:// nrs.harvard.edu/urn-3:HUL.InstRepos:dash.current.terms-of-use\#LAA

\section{Share Your Story}

The Harvard community has made this article openly available.

Please share how this access benefits you. Submit a story.

\section{Accessibility}




\title{
SURVIVE ANOTHER DAY: USING CHANGES IN THE COMPOSITION OF INVESTMENTS TO MEASURE THE COST OF CREDIT CONSTRAINTS
}

\author{
Luis Garicano and Claudia Steinwender*
}

Abstract-We introduce a novel empirical strategy to measure the size of credit shocks. Theoretically, we show that credit shocks reduce the value of long-term relative to short-term investments. Empirically, we can therefore compare the reduction of long-term relative to short-term investments within firms, allowing for firm-times-year fixed effects. Using Spanish firmlevel data, we estimate the credit crunch to be equivalent to an additional tax rate of around $11 \%$ on the longest-lived capital. To pin down credit constraints as the underlying cause, we apply triple-differences strategies using foreign ownership or precrisis debt maturity.

\section{Introduction}

$\mathrm{S}$ TUDYING the impact of credit shocks on investment empirically requires solving an identification problem: separating the impact of the supply of credit from the impact of the aggregate demand shock that usually takes place concurrently. To do this, the more recent literature has proposed a within-firm estimator that holds the firm constant and compares the effect of different lenders on the same firm. ${ }^{1}$ Here, we propose an alternative within-firm estimator, using variation in different investment duration classes within a firm.

Our strategy exploits the differential impact of demand shocks and liquidity constraints on the composition of investments. As we show formally in a simplified version of Aghion et al. (2009), absent liquidity constraints, firms equalize the value of the marginal dollar on short-term and long-term investments. However, under liquidity constraints, long-term investments involve a risk, since the firm may have to liquidate before the payoff period. This creates a wedge between the value of short- and long-term investments: Firms are willing to give up some future expected payoffs in order to increase the probability of surviving another day.

Our theoretical discussion suggests to us a precise empirical strategy. Assuming that demand shocks affect shortterm and long-term investments within firms similarly (an assumption that we discuss in detail), the difference between

Received for publication April 30, 2014. Revision accepted for publication July 1, 2015. Editor: Mark W. Watson.

* Garicano: London School of Economics, CEPR, and Centre for Economic Performance; Steinwender: Harvard Business School and Centre for Economic Performance.

We thank attendants at the LSE/CEP Labour Markets Workshop, the European Central Bank's and Bruegel's Economic Adjustment in the Euro Area conference, at the Toulouse Network on Information Technology, at the Gerzensee Finance Symposium, and the ECB Research Department seminar, as well as Daron Acemoglu, George-Marios Angeletos, Samuel Bentolila, and, especially, Daniel Paravisini, who made a crucial suggestion that underpins much of what follows. We acknowledge financial support from McKinsey \& Co. and the London School of Economics for purchasing the Spanish firm level data set.

A supplemental appendix is available online at http://www.mitpress journals.org/doi/suppl/10.1162/REST_a_00566.

${ }^{1}$ See, for example, Gan (2007), Khwaja and Mian (2008), Paravisini (2008), Iyer et al. (2014), Jimenez et al. (2010), Iyer and Peydró (2011), Schnabl (2012), Jimenez et al. (2012), and Paravisini et al. (2015). the longer-term and the shorter-term investment, if positive, is equal to a first-order approximation of the impact of the credit shock. A crucial advantage of our strategy is that it allows us to examine the shift in the composition of investment within firms before and after a financial shock, including firm-times-year fixed effects to make sure that neither demand shocks nor unobserved heterogeneity between firms bias the estimated impact of credit constraints.

Our identification strategy requires formulating a taxonomy of investments by their time to payoff, or durability. Surveying an extensive existing literature on the relative durability of different investment categories, we conclude that the shortest-lived investment is advertising, followed by IT, R\&D, with fixed capital investment like equipment and machinery being, on average, the longest lived.

To conduct our empirical analysis, we need two things: a credit crisis and detailed data about different investment types. In the case of Spain, both are available. We use the financial crisis in 2008 as an exogenous shock to credit supply. This is possible because this crisis was, at its core, a banking crisis. Previous research has established that the reduced bank liquidity translated into a reduction of credit supply to firms. ${ }^{2}$ This is particularly true for the case of Spain, where the liquidity crisis was exceptionally severe, despite the fact that the European Central Bank engaged as a lender of last resort (Drechsler et al., 2016). Jimenez et al. (2012) show that weaker banks deny more loans, even when the loans are identical, and that firms usually cannot substitute the weak bank with another bank. ${ }^{3}$ For Spain, detailed investment data is also available. We use a rich, high-quality, long-term panel data set of manufacturing firms that breaks up investment into six categories: advertising, IT, R\&D, vehicles, machinery, and furniture.

Applying our estimation strategy to the Spanish data, we find that after the financial crisis, the longest-term investments were reduced by 17 percentage points more than shortest-term investments. Given our theory, this is equivalent to an $11 \%$ incremental tax rate on the longest-term investment.

The second part of our empirical analysis aims to more precisely pin down credit constraints as the mechanism leading to the change in investment patterns (as in Bernanke \& Gertler, 1989). If credit constraints were indeed the cause of

2 For example, Iyer et al. (2014), Paravisini et al. (2015), Ivashina and Scharfstein (2010), Adrian, Colla, and Shin (2012), and Santos (2011) for the financial crisis in 2008 and Chava and Purnanandam (2011) for the Russian crisis in 1998 .

${ }^{3}$ Bentolila et al. (2013) show that firms that borrowed more from weak financial institutions that were later bailed out (almost all being savings banks, or Cajas de Ahorros) reduced employment by an additional 3.5 to 5 percentage points relative to firms that borrowed from healthier ones. 
the change, we should see a stronger effect for firms that were more affected by them. In triple-differences analyses, we use two ways, suggested by the literature, to identify those firms: domestic firms (as opposed to foreign ones, which typically have access to external finance through their parent companies), and firms with a lot of mature debt that needs to be rolled over at the beginning of the crisis.

Our triple-differences analysis using nationality of ownership may still fail to convince us, since domestic and foreign-owned firms differ among a variety of other dimensions besides their access to external funding. Therefore, we show that our results survive a variety of robustness checks. First, we use only multinational firms for our comparison: all are large, have subsidiaries in many countries, and are heavily export oriented. Second, we use an inverse propensity score reweighting scheme based on the size, growth, export status, and export development of firms before the financial crisis. Third, Spanish firms are smaller, so we control for firm size. Fourth, the exit rates of Spanish and foreign firms are not statistically significantly different, so compositional effects are not driving our results. Finally, the data show no difference between Spanish and foreign firms in the maturities of liabilities after the crisis.

In the second triple-differences analysis, we use the ratio of short-term debt over total debt to identify firms with a lot of mature debt that needs to be rolled over at the beginning of the crisis. This measure is arguably superior to ownership, because it is less likely to be correlated with other firm characteristics that might also affect investment behavior.

Since the credit squeeze in Spain went hand-in-hand with a recession, we carefully empirically evaluate three theoretical channels through which a demand shock could confound our estimates. The first hypothesis we label the interest rate channel and the substitution effect. It argues that due to a demand-driven reduction in interest rates, firms will substitute (contrary to our findings) short-term with long-term investments. If this is true, our estimates are a lower bound of the true effect. Another hypothesis, labeled differential impact of uncertainty, argues that a recession driven increase in uncertainty might lead firms to reduce long-term investments by more than short-term investments. However, our triple differences specifications allow us to include categoryyear fixed effects to control for recession driven changes in the composition of investment. Another hypothesis, which we label differential depreciation, argues that, due to the different depreciation rates across investment types, the same desired fall in capital stock due to a demand shock would translate into different percentage changes in long-term and short-term investments. However, a different normalization of investment, by capital stock, shows that this explanation is also not driving our results. In any case, a negative demand shock should be reflected in the output of firms, which we test for. Furthermore, sales as a direct firm-level measure of the demand shock are not showing the same effects on investment pattern as our measures for credit constraints.
Our finding that credit constraints induce firms to sacrifice long-term future profits in order to guarantee survival for another day complements a large body of literature showing that financially constrained firms invest less. ${ }^{4}$ This is also the case for recent studies that use the worldwide financial crisis in 2007-2008 as an exogenous shock to the credit supplied by banks. ${ }^{5} \mathrm{~A}$ smaller set of literature has studied how credit rationing affects the composition of firm investments but do not offer an explanation why certain investment types might be more affected than others. ${ }^{6}$

Beyond these substantive findings, our paper points a way forward methodologically to learn about credit shocks. The rotation in the investment vector toward the present and away from the future informs us about the existence and the size of the credit crunch.

\section{Theoretical Framework and Identification}

Most theoretical analysis of liquidity constraints aggregates all investment into a single decision (Kiyotaki \& Moore, 1997). Instead, we assume that a profit-maximizing firm can choose between two types of investment: short-term investments $k_{t}$ yield an immediate payoff $f\left(k_{t}\right)$, while longterm investments $z_{t}$ yield a higher payoff $(1+\rho) f\left(z_{t}\right)$, which is paid out at a later period. To capture this trade-off, we rely on a model that is a simplified version of Aghion et al. (2009). The key difficulty of firms is that with probability $1-\lambda_{t+1}$, a liquidity crisis in the interim period before the payoff of the long-term investment is realized, which may force the firm to liquidate. Thus, the probability of survival $\lambda_{t+1}$ measures the probability that the entrepreneur will have enough funds to cover the liquidity shock and is allowed to depend on the levels of short- and long-term investments. Specifically, reallocating investments from long to short term increases the probability of survival, $\left(\frac{\partial \lambda_{t+1}}{\partial k_{t}}-\frac{\partial \lambda_{t+1}}{\partial z_{t}}\right)>0$. The choice of how much short-run and long-run investment to undertake is then given by

$$
\max _{k_{t}, z_{t}} \boldsymbol{E}_{t}\left[f\left(k_{t}\right)+\beta \lambda_{t+1}(1+\rho) f\left(z_{t}\right)-q_{t} k_{t}-q_{t} z_{t}\right],
$$

where $\lambda_{t+1}$ measures the probability that the entrepreneur will have enough funds to cover the liquidity shock, $\rho$ is the additional productivity of long-term investment, and the rest of terms have their usual meanings.

Combining the two first-order conditions with respect to $k$ and $z$, we obtain the marginal condition,

$$
\boldsymbol{E}_{t}\left[f^{\prime}\left(k_{t}\right)\right]=\beta \boldsymbol{E}_{t}\left[\left(1-\tau_{t+1}\right)(1+\rho) f^{\prime}\left(z_{t}\right)\right],
$$

${ }^{4}$ Whited (1992), Carpenter et al. (1994), Hubbard, Kashyap, and Whited (1995), Bernanke, Gertler, and Gilchrist (1996, 1999), Kaplan and Zingales (1997), Lamot (1997), Cleary (1999), Klein, Peek, and Rosengren (2002), Amiti and Weinstein (2013), Fazzari, Hubbard, and Petersen (1988).

${ }^{5}$ Campello, Graham, and Harvey (2010), Duchin, Ozbas, and Sensoy (2010), Almeida et al. (2012), Kuppuswamy and Villalonga (2016).

6 See Eisfeldt and Rampini (2007) for the allocation of investment between new and used capital, as well as Campello et al. (2010), who point out that firms cut technology and marketing investment by more than capital investment. 
where

$$
\tau_{t+1}=\left(1-\lambda_{t+1}\right)+\left(\frac{\partial \lambda_{t+1}}{\partial k_{t}}-\frac{\partial \lambda_{t+1}}{\partial z_{t}}\right) \frac{f\left(z_{t}\right)}{f^{\prime}\left(z_{t}\right)} .
$$

This contrasts with the first best, absent liquidity shocks, when it should be the case that the marginal value of a dollar is equalized across both types of investments:

$$
\boldsymbol{E}_{t}\left[f^{\prime}\left(k_{t}\right)\right]=\beta \boldsymbol{E}_{t}\left[(1+\rho) f^{\prime}\left(z_{t}\right)\right] .
$$

Thus, the risk that the firm will run out of cash in period $t+1$ works exactly like a tax on investment $\tau_{t+1}$ and reduces the value of the (a priori more profitable) long-term investments relative to the first best. The first term of this wedge, $\left(1-\lambda_{t+1}\right)$, captures the probability of failure. The second term captures the marginal change in this probability as we reallocate investment from long term to short term. Given that reallocating investments from long term to short term increases the probability of survival, the tax wedge $\tau_{t+1}>0$. Hence, the propensity for reallocation away from long-term investment opportunities to short-term ones is higher-the higher the probability of avoiding bankruptcy by doing this, the higher the probability of not having enough liquidity next period, and the lower the marginal productivity of long-run investments.

The model predicts that credit-constrained firms will reduce long-term investment by more than short-term investment in order to secure survival. Our theoretical framework suggests a new empirical strategy, closely linked to the theory, that can help us to identify credit shocks.

Suppose that there are good ex ante reasons to expect liquidity to be plentiful before the shock to credit supply (denoted by subscript $b$ ) and to expect liquidity to be scarce after the credit shock (denoted by subscript $a$ ). Then we have from equation (2) that for a given firm $i$,

$$
f^{\prime}\left(k_{b}^{i}\right)=\beta(1+\rho) f^{\prime}\left(z_{b}^{i}\right) \varepsilon_{b}^{i},
$$

assuming $\varepsilon_{i} \sim \ln N\left(1, \sigma^{2}\right)$ and i.i.d. Using a Cobb-Douglas function $y=k^{\alpha}$ to get exact expressions (everything goes through as a log-linear approximation otherwise), taking logs, and substracting the expression from the equivalent one from equation (1) suggests the following differencein-differences estimator as the way to identify the wedge introduced by the liquidity shock in firm $i$,

$$
\begin{aligned}
& (1-\alpha)\left(\left(\ln z_{a}^{i}-\ln z_{b}^{i}\right)-\left(\ln k_{a}^{i}-\ln k_{b}^{i}\right)\right) \\
& \quad=\ln \left(1-\tau_{t+1}^{i}\right)+\ln \varepsilon_{a}^{i}-\ln \varepsilon_{b}^{i},
\end{aligned}
$$

where $\boldsymbol{E}\left(\ln \varepsilon_{a}^{i}-\ln \varepsilon_{b}^{i}\right)=0$.

Consider the following difference-in-differences specification using investment $I$ in investment category $c=\{k, z\}$ as a dependent variable,

$$
\begin{aligned}
\ln I_{i c t}= & \beta_{0}+\beta_{1} \times \text { crisis }_{t} \times \text { longterm }_{c}+\text { crisis }_{t} \\
& + \text { longterm }_{c}+v_{i c t}
\end{aligned}
$$

where crisi $_{t}$ is a dummy variable that turns 1 in the years of a financial crisis and longterm $_{c}$ is a dummy variable indicating a long-term investment. In this specification, the coefficient on the interaction term equals

$$
\beta_{1}=\boldsymbol{E}\left(\left(\ln I_{i z a}-\ln I_{i z b}\right)-\left(\ln I_{i k a}-\ln I_{i k b}\right)\right) .
$$

This last expression equals, up to a factor, the wedge between long-term and short-term investments, which has a clear economic interpretation in the theory:

$$
\beta_{1}=\frac{\boldsymbol{E}\left(\ln \left(1-\tau_{t+1}\right)\right)}{(1-\alpha)} .
$$

In reality, and in our data, we have more than two investment categories; thus, we generalize (3) to multiple investment types. Furthermore, we can include firm times year fixed effects as well as investment category fixed effects to make sure that same structural equation above is identified. This leads to our estimated regression equation:

$$
\begin{aligned}
\ln I_{i c t}= & \beta_{0}+\beta_{1} * \text { crisis }_{t} * \text { duration-of-inv } \\
& + \text { firm } * \text { year } F E_{i t}+\text { cat } F E_{c}+v_{i c t}
\end{aligned}
$$

\section{Data}

For the theory to guide our empirical work, we rely on an extensive literature-for example, by accountants and growth accountants - to provide a taxonomy of tangible and intangible investments by the horizon over which they pay off, or their durability. ${ }^{7}$

The shortest-lived investment category is that of brand equity and advertising. Landes and Rosenfield (1994) estimate the annual rates of decay of advertising to be more than $50 \%$ for most industries, using twenty two-digit SIC manufacturing and service industries. For a number of industries, they even find that the effect of advertising does not persist until the following year. A more recent literature review by Corrado, Hutten, and Sichel (2009) concludes that the depreciation rate for advertising is $60 \%$, the value we use. They also note that $40 \%$ of advertising expenditure is spent on advertisements that last less than a year (e.g., on "this week's sale"), which partly explains the short-lived impact of advertising.

The literature reports a depreciation rate of around $30 \%$ for software investments. The Bureau of Economic Analysis (1994) estimated a depreciation rate of $33 \%$ for a five-year service life, according to Corrado et al. (2009). Tamai and Torimitsu (1992) report a nine-year average life span for software (between two and twenty years), relying on survey evidence. The Spanish accounting rules give a depreciation rate of $26 \%$ for IT equipment and software, so we use a value of around $30 \%$ as summarizing the evidence in our main specification.

\footnotetext{
7 The text is summarized in table form in the online appendix.
} 
TABLE 1.-Summary Statistics

\begin{tabular}{|c|c|c|c|c|}
\hline & \multicolumn{2}{|c|}{ Mean (Standard Error) } & \multirow[b]{2}{*}{ Change } & \multirow[b]{2}{*}{ Change in $\%$} \\
\hline & $\begin{array}{c}\text { Before Crisis } \\
(2003-2007)\end{array}$ & $\begin{array}{l}\text { After Crisis } \\
(2008-2010)\end{array}$ & & \\
\hline \multicolumn{5}{|c|}{ Investment categories, mn EUR (ordered by depreciation rate) } \\
\hline Advertising & $\begin{array}{r}150.99 \\
(9.86)\end{array}$ & $\begin{array}{l}118.77 \\
(12.79)\end{array}$ & $-32.22^{* *}$ & $-21.3 \%^{* *}$ \\
\hline IT & $\begin{array}{c}6.20 \\
(0.52)\end{array}$ & $\begin{array}{c}3.86 \\
(0.53)\end{array}$ & $-2.34^{* * *}$ & $-37.7 \%$ *** \\
\hline $\mathrm{R} \& \mathrm{D}$ & $\begin{array}{l}1.12 \\
(0.13)\end{array}$ & $\begin{array}{l}1.05 \\
(0.16)\end{array}$ & -0.07 & $-6.3 \%$ \\
\hline Vehicles & $\begin{array}{l}4.20 \\
(0.60)\end{array}$ & $\begin{array}{l}6.10 \\
(2.33)\end{array}$ & 1.90 & $45.2 \%$ \\
\hline Machinery & $\begin{array}{l}198.57 \\
(13.86)\end{array}$ & $\begin{array}{l}141.78 \\
(13.49)\end{array}$ & $-56.79^{* * *}$ & $-28.6 \% \%^{* * *}$ \\
\hline Furniture and office equipment & $\begin{array}{l}37.73 \\
(4.71)\end{array}$ & $\begin{array}{l}33.98 \\
(5.35)\end{array}$ & -3.75 & $-9.9 \%$ \\
\hline \multicolumn{5}{|l|}{ Credit } \\
\hline Credit ratio (total credit/total assets) & $\begin{array}{c}0.57 \\
(0.00)\end{array}$ & $\begin{array}{c}0.54 \\
(0.00)\end{array}$ & $-0.03^{* * *}$ & $-5.3 \% \%^{* * *}$ \\
\hline Credit cost $(\%)^{\mathrm{a}}$ & $\begin{array}{l}4.06 \\
(0.02)\end{array}$ & $\begin{array}{l}4.28 \\
(0.03)\end{array}$ & $0.22^{* * *}$ & $5.4 \%{ }^{* * *}$ \\
\hline
\end{tabular}

${ }^{\text {a }}$ Total cost of a credit (incl. interest rates, but also other fees) as a percentage of obtained credit.

The evidence on the average depreciation rates and average life spans of $R \& D$ capital is extensive, and estimates range from $10 \%$ to $30 \%$. Pakes and Schankerman $(1984,1986)$ propose $25 \%$ based on five European countries, and $11 \%$ to $26 \%$ in a later study for Germany, the United Kingdom, and France. Nadiri and Prucha (1996) estimated a rate of $12 \%$ for $R \& D$, while Bernstein and Mamuneas (2006) estimate the depreciation rate at $18 \%$ to $29 \%$. Corrado et al. (2009) review the literature and settle on a value of $20 \%$ for $\mathrm{R} \& \mathrm{D}$, which is the value we use.

Longer-lived investments include fixed tangible assets like machinery, vehicles, and other equipment. The Spanish accounting rules yield similar values for these types of investment, with vehicles having a depreciation rate of around $16 \%$, machinery around $12 \%$, and furniture and office equipment around $10 \% .8$

We rely on the Encuesta Sobre Estrategias Empresariales (ESEE), a panel of Spanish manufacturing firms, for data on investment. This data set has been collected by the Spanish government and the SEPI foundation every year since 1990, covering around 1,800 firms per year. ${ }^{9}$ We used data from 2003 to 2010 in our analysis.

In contrast to balance sheet firm-level databases, the Spanish data cover a number of different investment choices made by firms that can be linked to our investment categories based on time to payoff: advertising expenditure; IT expenses; R\&D expenses; and investment in vehicles, machinery, and furniture and office equipment. Besides these main investment variables, we also have data on the credit ratio of firms

${ }^{8}$ See http://www.individual.efl.es/ActumPublic/ActumG/MementoDoc /MF2012_Coeficientes\%20anuales\%20de\%20amortizacion_Anexos.pdf. The BEA's accounting rules are very similar: http://www.bea.gov/scb /account_articles/national/wlth2594/tableC.htm.

${ }_{9}^{9} \mathrm{See}$ https://www.fundacionsepi.es/investigacion/esee/en/spresentacion asp. and other complementary variables such as sales, exports, and foreign ownership.

Table 1 presents summary statistics for the main variables that are the object of our analysis, before and after the crisis. ${ }^{10}$ The data shows that investment in all categories fell after the financial crisis in 2008. ${ }^{11}$ However, ex ante, it is not clear whether this investment drop is triggered by the credit squeeze or the adverse demand shock. Our empirical strategy aims to disentangle these effects.

The credit crunch triggered by the financial crisis is also reflected in the Spanish credit data: total credit as a percentage of total assets (the credit ratio) fell by 3 percentage points after the crisis, from $57 \%$ to $54 \%$. At the same time, observed average credit cost increased by 0.22 percentage points, from $4.06 \%$ to $4.28 \%$. This is obviously a lower bound on the increased cost, as firms often simply could not get access to credit. Together with the observed immediate drop in the credit ratio, this suggests that we observe a credit supply rather than a credit demand shock immediately after the financial crisis hit.

\section{Results}

Table 2 presents our main results from estimating regression equation (5). Standard errors are clustered at the firm level, allowing for autocorrelation across time and across

10 Two other investment categories, land and buildings, are available in our data. These are very long-lived investments and showed the largest statistically significant drop. However, since the financial crisis in Spain was based on a real estate bubble, which led to falling real estate prices, it seemed safer to exclude land and building from our analysis, as it would have biased our results toward finding our hypothesized effect.

11 The single exception is vehicles, where a "cash for clunkers" plan (Plan Renove) was introduced by the government. Using a specification similar to that of Mian and Sufi (2012), we can show that this plan had a similar impact to the one documented in the United States. 
TABLE 2.-MAIN Results

\begin{tabular}{|c|c|c|c|c|c|}
\hline & $\begin{array}{c}(1) \\
\ln (\text { inv })\end{array}$ & $\begin{array}{c}(2) \\
\ln (\text { inv })\end{array}$ & $\begin{array}{c}(3) \\
\text { Inv/stock }\end{array}$ & $\begin{array}{c}(4) \\
\text { Inv/stock }\end{array}$ & $\begin{array}{c}(5) \\
\ln (\text { inv })\end{array}$ \\
\hline $\begin{array}{l}\text { (1/depreciation rate }) \times \\
\text { after } 2008 \text { dummy }\end{array}$ & $\begin{array}{l}-0.020^{* * *} \\
(0.006)\end{array}$ & $\begin{array}{l}-0.072^{* * *} \\
(0.016)\end{array}$ & $\begin{array}{l}-0.346^{* * *} \\
(0.121)\end{array}$ & $\begin{array}{l}-0.236^{* * *} \\
(0.073)\end{array}$ & \\
\hline $\begin{array}{l}(\text { Year }=2004) \times \\
\quad(\text { Time-to-payoff measure })\end{array}$ & & & & & $\begin{array}{r}-0.003 \\
(0.008)\end{array}$ \\
\hline $\begin{array}{l}(\text { Year }=2005) \times \\
\quad(\text { Time-to-payoff measure })\end{array}$ & & & & & $\begin{array}{c}-0.003 \\
(0.009)\end{array}$ \\
\hline$($ Year $=2006) \times$ & & & & & 0.005 \\
\hline $\begin{array}{l}\text { (11me-to-payoft measure }) \\
(\text { Year }=2007) \times\end{array}$ & & & & & $\begin{array}{c}(0.009) \\
0.004\end{array}$ \\
\hline (Time-to-payoff measure) & & & & & $(0.009)$ \\
\hline$($ Year $=2008) \times$ & & & & & $\begin{array}{r}-0.003 \\
(0.010)\end{array}$ \\
\hline$($ Year $=2009) \times$ & & & & & $-0.026^{* *}$ \\
\hline (Time-to-payoff measure) & & & & & $(0.010)$ \\
\hline $\begin{array}{l}(\text { Year }=2010) \times \\
\quad(\text { Time-to-payoff measure })\end{array}$ & & & & & $\begin{array}{l}-0.032^{* * *} \\
(0.010)\end{array}$ \\
\hline Observations & 43,900 & 88,331 & 43,900 & 88,331 & 43,900 \\
\hline Partial $R^{2}$ & 0.582 & 0.235 & 0.004 & 0.003 & 0.583 \\
\hline Including 0's & & Yes & & Yes & \\
\hline
\end{tabular}

All regressions include category FE and firm $\times$ year FEs. All standard errors are clustered at the firm level, allowing for autocorrelation across time and across investment categories within the firm. $* * * p<0.01$ ${ }^{* *} p<0.05, * p<0.1$

investment categories within the firm. ${ }^{12}$ All columns include firm times year fixed effects. If demand shocks do not have a differential effect across investment types, we manage to control for them in this way. The coefficient on the interaction term in column 1 is negative, implying that investments with a longer time to payoff fell more after the financial crisis than investments with a shorter time to payoff. Note that in contrast to other papers on the effect of credit squeezes on investment, this is likely to be a lower bound of the true estimate; if demand shocks affect investment types differentially, they are likely to affect investments with a shorter time to payoff by more than investments with a longer time to payoff (the recession will, after all, finish at some point in the future). It is common that investment observations are 0 and thus excluded from the analysis (in logs). Column 2 codes the 0 's as 1 euro and thus includes all those observations. The results are substantially stronger, suggesting our baseline analysis is very conservative. Columns 3 and 4 normalize investment by the capital stock at the beginning of period. ${ }^{13}$ Column 3 excludes investments of 0 , whereas column 4 includes it. The different ways of normalizing investment do not affect the results; a highly significant negative effect is visible across all specifications.

In the online appendix, we conduct a variety of robustness checks. For example, we use the rank of investment types

\footnotetext{
${ }^{12}$ Bertrand, Duflo, and Mullainathan (2004) point out that serially correlated outcomes in differences-in-differences estimations produce serially correlated residuals, and standard errors need to be adjusted accordingly. They recommend clustering errors at the group level if the number of groups is large enough (e.g., 50). For our regression, this would mean clustering at the investment category level; unfortunately, our number of categories is too small for clustering (six categories). We decided to correct for autocorrelation of the residuals by clustering at the firm level instead, which allows for arbitrary serial correlation over time, as well as across investment categories within a firm.

${ }^{13}$ See the online appendix for details.
}

as an alternative measure for time to payoff, we regroup investment categories, we use the depreciation rate directly as regressor, and we omit one investment category at a time. Our results are robust to all of these specifications.

How can we interpret the economic significance of our effect? In our preferred specification in column 1 in table 2 , investment falls by 2 percentage points for a unit increase in the inverse depreciation rate. This leads to our main result: investment in office equipment (the category with the lowest depreciation rate) gets reduced by 17 percentage points more than advertising (the category with the highest depreciation rate), a sizable difference..$^{14}$

Our theory suggests interpreting this result as a tax on capital. Given that the investment gap between capital with the shortest and longest time to payoff ( $\beta_{1}$ in the theory) is $17 \%$ and using $\alpha=1 / 3$ (the capital share) in equation (4), our results mean that the credit crunch is equivalent to an $11 \%$ tax on the long-run investments relative to the shortest-run one. 15

So far we have pooled the estimated effect across all years before and after the crisis, respectively. In order to make sure we are capturing the effect of the credit squeeze instead of something else, we check whether the timing of the effect really coincides with the credit squeeze and conduct a placebo test by allowing the interaction term to vary by year. The results in column 5 of table 2 support our story: the coefficient becomes negative (but still insignificant) in the year 2008 and becomes even more negative and highly significant thereafter. This timing is consistent with the development of the credit squeeze. After the failure of Lehman Brothers in September 2008, conditions tightened severely. The first full

\footnotetext{
${ }^{14}$ See the online appendix for details.

${ }^{15} \tau_{t+1}=1-\exp (-0.17 \times 2 / 3)=10.6 \%$.
} 
TABle 3.-Mechanism: CRedit SQUeEZE

\begin{tabular}{|c|c|c|c|c|c|}
\hline & (1) & (2) & (3) & (4) & (5) \\
\hline $\begin{array}{l}\text { Dummy if after crisis } \\
\quad(\text { year }=2008 \text { and after })\end{array}$ & $\begin{array}{c}-0.015^{* * *} \\
(0.004)\end{array}$ & $\begin{array}{l}-0.016^{* * *} \\
(0.004)\end{array}$ & $\begin{array}{c}0.006 \\
(0.010)\end{array}$ & & \\
\hline $\begin{array}{l}\text { Interaction term (Spanish firm } \\
\text { dummy }) \times(\text { after 2008) }\end{array}$ & & & $\begin{array}{l}-0.025^{* * *} \\
(0.010)\end{array}$ & $\begin{array}{l}-0.025^{* * *} \\
(0.010)\end{array}$ & $\begin{array}{l}-0.035^{* * *} \\
(0.010)\end{array}$ \\
\hline $\ln$ (industry exports to EU) & & $\begin{array}{c}0.021 \\
(0.037)\end{array}$ & $\begin{array}{c}0.024 \\
(0.037)\end{array}$ & $\begin{array}{c}0.058 \\
(0.040)\end{array}$ & \\
\hline ln(industry exports to World) & & $\begin{array}{r}-0.009 \\
(0.037)\end{array}$ & $\begin{array}{r}-0.013 \\
(0.037)\end{array}$ & $\begin{array}{r}-0.056 \\
(0.041)\end{array}$ & \\
\hline $\ln$ (industry output) & & $\begin{array}{c}0.013 \\
(0.013)\end{array}$ & $\begin{array}{c}0.014 \\
(0.013)\end{array}$ & $\begin{array}{c}0.005 \\
(0.015)\end{array}$ & \\
\hline Observations & 13,915 & 13,915 & 13,897 & 13,897 & 13,897 \\
\hline Partial $R^{2}$ & 0.004 & 0.005 & 0.007 & 0.002 & 0.003 \\
\hline Number of firms FE & 2,650 & 2,650 & 2,650 & 2,650 & 2,650 \\
\hline Firm FEs & Yes & Yes & Yes & Yes & Yes \\
\hline Year FEs & & & & Yes & \\
\hline Industry $\times$ Year FEs & & & & & Yes \\
\hline
\end{tabular}

year in which the effects of the credit crunch were fully spread was 2009.16

Now we aim to further pin down credit constraints as cause for the observed change in the investment behavior as opposed to other mechanisms, which could lead to similar effects, such as an increase in uncertainty (Bloom, 2009; Bernanke, 1983), which could increase the option value of waiting. If our hypothesis is true, we should expect to see a differential effect on firms that are more affected by the credit crunch.

The literature suggests two types of affected firms: (1), domestic firms, since foreign firms have access to external finance in less affected countries via their parent companies (Desai, Foley, \& Hines, 2004; Desai, Foley, \& Forbes, 2008; Kalemli-Ozcan, Kamil, \& Villegas-Sanchez, 2010), and (2), firms that happen to have a lot of mature debt at the beginning of a financial crisis, because they experience difficulty in rolling their debt over during a credit crunch (Almeida et al., 2012).

We start our analysis by looking at foreign versus domestic firms. If it is true that foreign firms are less affected by a credit squeeze, then we should observe a fall in the credit ratio only for domestic firms. Table 3 tests this. In column 1, we find that the credit ratio, defined by total credit divided by assets, on average fell after the crisis, a result that was already visible from the summary statistics in table 1 . Column 2 controls for industry-specific demand conditions using the industry's exports and size as a time-varying control. Also, firm-level fixed effects allow us to control for any other timeinvariant unobserved firm heterogeneity.

Column 3 compares the drop between Spanish and foreign-owned firms and answers the following question: Comparing two firms of the same size that are facing the same demand conditions, does the firm that happens to be Spanish suffer a significant drop in credit after the crisis?

\footnotetext{
${ }^{16}$ In the online appendix, we provide robustness checks using alternative definitions of time to payment and $F$-tests on the equality of the coefficients to the one in 2007.
}

The answer is unambiguous and highly significant: Spanish firms suffer a drop in credit of around 2.5 percentage points after the crisis compared to non-Spanish firms. In column 4 we add time fixed effects to capture any common time-varying aspects of the crisis that are not yet captured by industry exports or size, and the effect remains the same. Column 5 is our most demanding specification, which allows for industry-specific time effects (and thus absorbs our previous industry-specific controls), and the result is again stronger, with Spanish firms facing a credit drop of 3.5 percentage points. This is equivalent to a $6.1 \%$ drop in credit relative to the 2007 baseline of $57.8 \%$ credit to assets for Spanish firms before the crisis.

Thus, under our hypothesis, the shift in the composition of investment (if linked to credit) should occur only in Spanish firms. In table 4 we start the analysis by running the main regression separately for domestic and foreign firms. Only the effect in column 1 is negative and statistically significant, suggesting that only domestic firms cut their long-term investment relatively more than their short-term investment. There is no significant difference across investment types for foreign-owned firms. In columns 3 and 4, we conduct placebo tests by allowing the interaction term to vary by year. Again, we see that the effect is driven by domestic firms, in line with our hypothesis. ${ }^{17}$

We can test this more formally by extending our analysis to a triple-difference estimation, comparing long-term versus short-term investments before and after the financial crisis in 2008 for Spanish versus foreign firms. This allows us to further challenge our results by including category $\times$ year fixed effects in addition to the firm $\times$ year fixed effects to control for the possibility that firms might reduce or increase investment in certain categories during recessions.

Table 5 shows the results of the triple difference specification. Column 1 repeats the main specification, column 2 shows the results of the triple difference estimation with

\footnotetext{
${ }^{17}$ In the online appendix, we provide $F$-tests for the equality of postcrisis coefficients to the 2007 coefficient.
} 
TABLE 4.-ForeIGN VERSUS DOMESTIC FIRMS

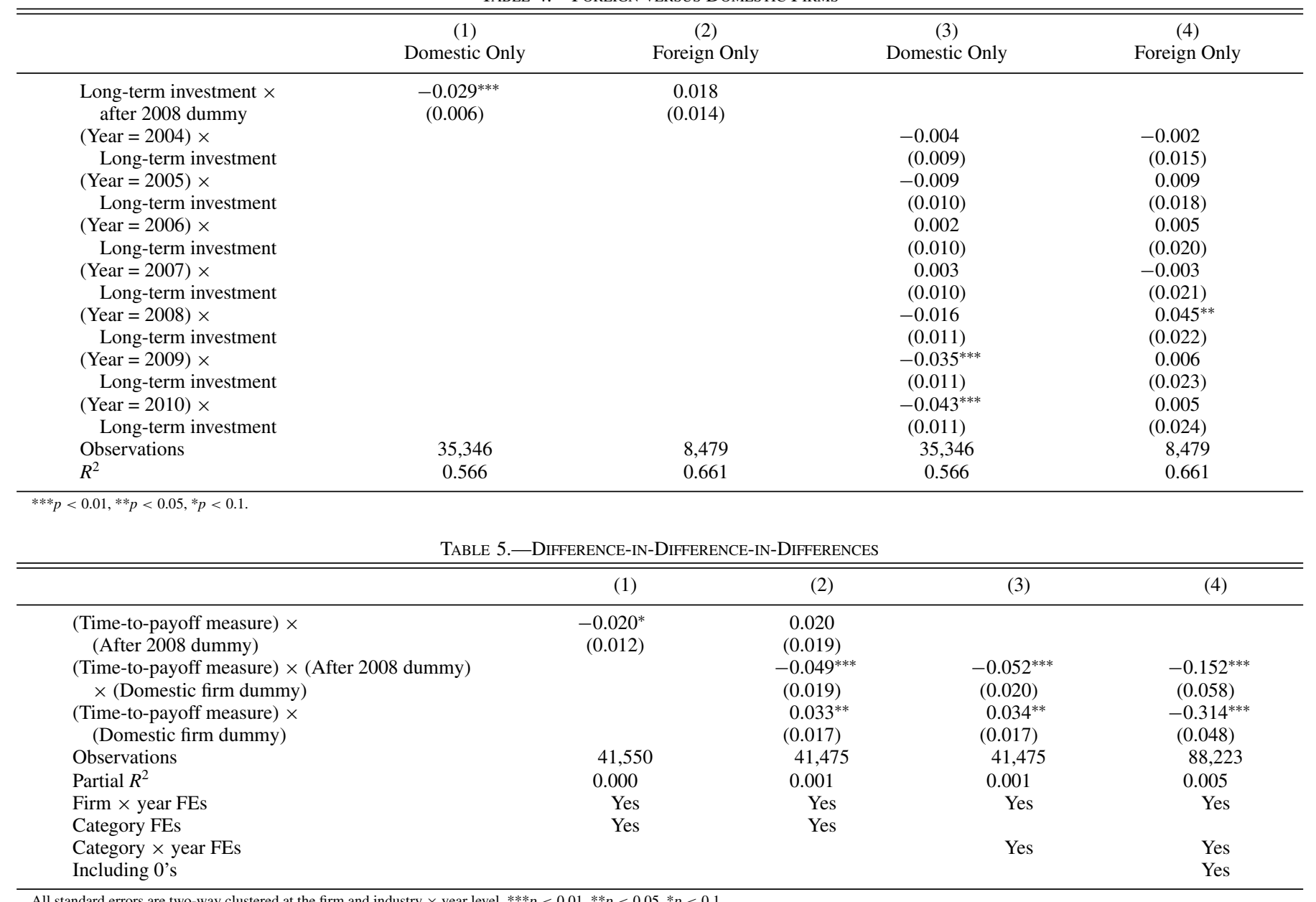

category fixed effects, and column 3 replaces them by the full category $\times$ year fixed effects. ${ }^{18}$ The triple difference estimation shows a significant differential negative effect for long-term investments after the crisis undertaken by Spanish firms. Column 4 codes the 0's as 1 euro and thus includes all the 0 investments. Again, the results are substantially stronger, suggesting our baseline analysis is very conservative.

The differential effects for domestic firms by investment category and over time are visualized in figure 1. Darker lines depict investment types with a longer time to payoff, for which we would expect a larger drop. The visual evidence is broadly in line with our hypothesis, as lighter lines show a smaller drop and darker lines show a larger drop after 2008. It is also notable that until 2007, there is no differential effect by investment types; the lines are all parallel and very close. The differential effect starts to come in only after 2007, when the credit crunch hits.

A worry is that domestic and foreign-owned firms differ among a variety of dimensions besides access to external

18 Note that the domestic firm dummy variable in the data is not time invariant, as it changes with ownership changes. However, there are very few of those in the data, and they are not driving our results.
Figure 1.-InVestment Change By InVestment Type, TRIPLE DifFERENCE ESTIMATION

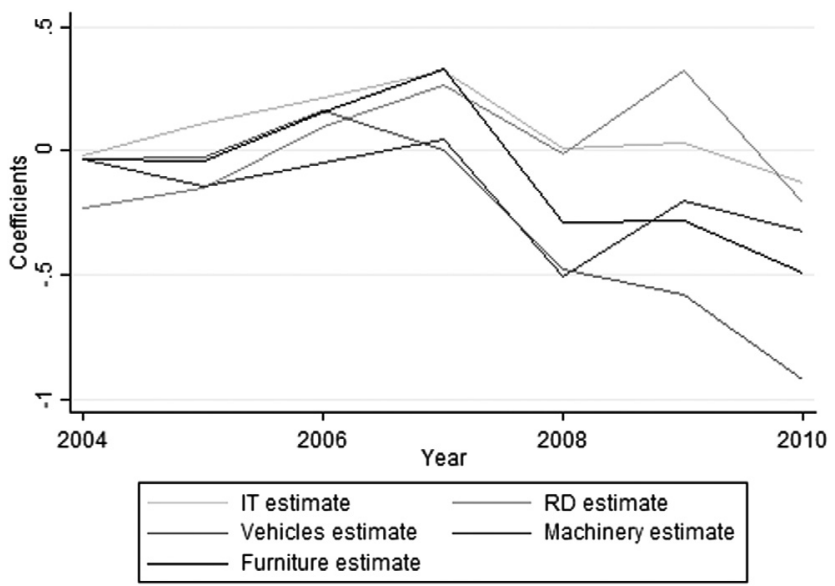

Darker lines depict investment types with a longer time-to-payoff, for which we would expect a larger drop.

funding. For example, Spanish-owned firms in our data are typically smaller and less likely to export and might therefore show a different investment behavior. To address this concern, table 6 conducts a variety of robustness checks. One dimension of time-varying, unobserved heterogeneity might 
TABle 6.-Robustness CheCKs Foreign versus Domestic Firms

\begin{tabular}{|c|c|c|c|c|c|}
\hline & (1) & (2) & (3) & (4) & (5) \\
\hline (Time-to-payoff measure) $\times$ & $0.034^{* *}$ & $0.031^{*}$ & 0.063 & 0.007 & 0.008 \\
\hline (Domestic firm dummy) & $(0.017)$ & $(0.017)$ & $(0.038)$ & $(0.015)$ & $(0.016)$ \\
\hline (Time-to-payoff measure) $\times$ & $-0.052^{* * *}$ & $-0.049^{* * *}$ & $-0.074^{*}$ & $-0.045^{* * *}$ & $-0.042^{* *}$ \\
\hline$($ After 2008$) \times($ Domestic firm $)$ & $(0.020)$ & $(0.019)$ & $(0.039)$ & $(0.018)$ & $(0.018)$ \\
\hline (Time-to-payoff measure) $\times$ & & & & $-0.013^{* * *}$ & \\
\hline $\ln ($ sales $)$ & & & & $(0.004)$ & \\
\hline (Time-to-payoff measure) $\times$ & & & & 0.002 & \\
\hline (After 2008 dummy) $\times \ln ($ sales $)$ & & & & $(0.006)$ & \\
\hline (Time-to-payoff measure) $\times$ & & & & & $-0.014^{* * *}$ \\
\hline $\ln (\mathrm{TFP})$ & & & & & $(0.005)$ \\
\hline (Time-to-payoff measure) $\times$ & & & & & 0.001 \\
\hline (After 2008 dummy) $\times \ln ($ TFP $)$ & & & & & $(0.007)$ \\
\hline Observations & 41,475 & 22,909 & 23,965 & 41,475 & 38,791 \\
\hline Partial $R^{2}$ & 0.001 & 0.001 & 0.004 & 0.003 & 0.002 \\
\hline Number of Firm $\times$ Year FE & 11,028 & 5,731 & 6,302 & 11,028 & 10,300 \\
\hline
\end{tabular}
category $\times$ year FEs. All standard errors are two-way clustered at the firm and industry $\times$ year level. $* * * p<0.01, * * p<0.05, * p<0.1$

be differences between companies that operate across countries and those that operate in a single country. Companies that operate in many countries belong to a corporate group, and this could provide them with advantages that go beyond their access to capital. For example, they might face a more diversified demand. Column 2 conducts our analysis only for companies that belong to a corporate group. Presumably most of them are multinationals. The results are remarkable. Even though the sample size drops substantially (by more than half), the effect remains very similar and highly significant. 19

Column 3 uses another way to make the control group of foreign firms a more suitable counterfactual for the treatment group of domestic firms by applying inverse propensity score weights. This type of matching estimator reweights each observation by its (inverse) propensity score (the likelihood that a firm belongs to the treatment group, that is, it is under Spanish ownership) in order to generate the same distribution of (observed) characteristics of treatment and control group, and therefore, we hope, also match the unobserved time-varying heterogeneity better. We construct propensity scores based on sales and export status (as these observables seem to be the major differences between Spanishand foreign-owned firms) of all pretreatment years based on a probit regression of the treatment on sales and export status in all years between 2003 and 2007. The predicted values of these regressions, $\widehat{\text { treat }}$, are then used to calculate inverse propensity score weights $p s w=\frac{\text { treat }}{1-\text { treat }}$ for each firm. We use these weights for all firms in the control group in our regression (for more details on the method, see DiNardo, Fortin, \& Lemieux. 1996 and Nichols, 2007, 2008). Our results in column 3 are robust to this test, suggesting that selection is not a major concern in our analysis.

\footnotetext{
${ }^{19}$ In the online appendix, we show that the results are consistent when using different definitions of multinationals, such as firms that have nonindustrial plants in foreign countries or those that have share holdings in foreign countries.
}

The last two columns in table 6 analyze whether firm size or productivity differences are driving the results by including interaction terms with $\ln$ (sales) and $\ln$ (TFP) besides the interaction term with domestic firms. ${ }^{20}$ However, both size and productivity fail to explain the differential drop in investment. The ownership interaction remains significant, and its magnitude is unchanged in spite of including this competing explanation.

A separate concern is the extent to which differential exit rates of Spanish and foreign-owned firms could explain these results. Suppose simply that "worse" firms are exiting. If "worse" firms are those that feature more long-term investments, then we shall see more short-term investment and less long-term ones in the surviving data. This seems unlikely a priori, as we tend to think of better firms as the ones doing more long-term investment. In any case, the exit rates among Spanish versus foreign firms are not statistically significantly different (consistent with our mechanism, as firms manage to avoid bankruptcy due to their changing investment behavior). ${ }^{21}$

A final concern is the mechanism through which this process takes place. Specifically, while we postulate in the theory that it takes place through the asset side of the balance sheet (firms have less access to credit in general and decide to cut long-term investments), an alternative hypothesis is that it takes place through the liability side (firms have less access to long-term credit and therefore cut longterm investment because otherwise they cannot match the liabilities and investments by debt maturity). To test this, in table 7 we check whether domestic firms suffered a differential drop in long-term credit (as a ratio of total credit) compared to foreign firms, using the same specification as in table 3. However, while Spanish firms suffer from access to credit in general as shown in table 3, there is no differential effect with respect to long-term credit as opposed to

\footnotetext{
${ }^{20}$ See the online appendix for details on TFP estimation.

${ }^{21}$ See the online appendix for details.
} 


\begin{tabular}{|c|c|c|c|c|c|}
\hline & (1) & (2) & (3) & (4) & (5) \\
\hline $\begin{array}{l}\text { Dummy if after crisis (year is }=2008 \\
\text { and after) }\end{array}$ & $\begin{array}{l}0.051^{* * *} \\
(0.005)\end{array}$ & $\begin{array}{l}0.050^{* * *} \\
(0.005)\end{array}$ & $\begin{array}{l}0.050^{* * *} \\
(0.011)\end{array}$ & & \\
\hline $\begin{array}{l}\text { Interaction term (Spanish firms) } \times \\
\quad(\text { after 2008) }\end{array}$ & & & $\begin{array}{c}0.000 \\
(0.012)\end{array}$ & $\begin{array}{c}0.001 \\
(0.012)\end{array}$ & $\begin{array}{c}0.000 \\
(0.013)\end{array}$ \\
\hline $\ln ($ industry exports to EU) & & $\begin{array}{c}-0.071 \\
(0.046)\end{array}$ & $\begin{array}{r}-0.073 \\
(0.046)\end{array}$ & $\begin{array}{c}-0.042 \\
(0.044)\end{array}$ & \\
\hline $\ln$ (industry exports to World) & & $\begin{array}{c}0.060 \\
(0.045)\end{array}$ & $\begin{array}{c}0.061 \\
(0.045)\end{array}$ & $\begin{array}{c}0.037 \\
(0.047)\end{array}$ & \\
\hline $\ln$ (industry output) & & $\begin{array}{l}-0.050^{* * *} \\
(0.018)\end{array}$ & $\begin{array}{c}-0.050^{* * *} \\
(0.018)\end{array}$ & $\begin{array}{r}-0.029 \\
(0.020)\end{array}$ & \\
\hline Observations & 14,410 & 14,410 & 14,392 & 14,392 & 14,392 \\
\hline Partial $R^{2}$ & 0.029 & 0.032 & 0.033 & 0.002 & 0.001 \\
\hline Number of firm FEs & 2,707 & 2,707 & 2,707 & 2,707 & 2,707 \\
\hline Firm FEs & Yes & Yes & Yes & Yes & Yes \\
\hline Year FEs & & & & Yes & \\
\hline Industry $\times$ Year FEs & & & & & Yes \\
\hline
\end{tabular}

TABle 8.-Short-Term CRedit Before Crisis

\begin{tabular}{lccc}
\hline \hline & $(1)$ & $(2)$ & $(3)$ \\
\hline (Time-to-payoff measure) $\times$ & $-0.052^{* * *}$ & $-0.042^{* * *}$ & $-0.086^{* * *}$ \\
(after 2008 dummy) $\times$ (treatment) & $(0.020)$ & $(0.011)$ & $(0.027)$ \\
(Time-to-payoff measure) $\times$ & $0.034^{* *}$ & $0.020^{*}$ & 0.019 \\
(treatment) & $(0.017)$ & $(0.011)$ & $(0.029)$ \\
Observations & 41,475 & 36,135 & 36,135 \\
Partial $R^{2}$ & 0.001 & 0.001 & 0.000 \\
\hline
\end{tabular}

This specification is equivalent to the triple-difference estimation conducted in column 3 in table 5 Column 1 uses domestic firms as the treatment variable as in our baseline specification. Column 2 uses a dummy variable if short-term credit with financial institutions/total credit is larger than average in 2007. Colith variable. All standard errors are two-way clustered at the firm and industry $\times$ year level. All regression
include firm $\times$ year FEs and category $\times$ year FEs. $* * * p<0.01, * * p<0.05, * p<0.1$.

short-term credit, so a differential liability matching does not explain our results.

An alternative approach to studying the mechanism that does not rely on using nationality of ownership as the driver of credit constraints is to use firms whose debt is maturing just before the crisis as a treatment group. These firms are likely to be more severely affected by the credit squeeze as they have to roll over their debt when the crisis starts. We use short-term credit with financial institutions divided by total credit in 2007, the year before the crisis, as a measure for more credit-constrained firms in table 8 . This measure is arguably a better one for credit constraints than ownership, as it is less likely to be correlated to other firm characteristics. Column 1 repeats our main specification from before, using domestic firms as treatment. Column 2 uses a dummy variable if this short-term credit ratio is larger than average, and column 3 uses the ratio itself as a continuous measure. Both columns show a very similar effect compared to our comparisons of domestic to foreign firms, and the magnitude is also similar: more-credit constrained firms cut long-term investment relatively more.

A concern for identification might be that the credit squeeze in Spain went hand in hand with a recession. Are we picking up the effects of credit constraints as opposed to a pure demand shock without financial frictions? We outline three theoretical arguments that show how a demand shock could affect long-term investments by more or by less than short-term investments. We then show that our empirical evidence is not consistent with a purely recession-driven explanation.

\section{A. The Interest Rate Channel and the Substitution Effect}

Contrary to the evidence we have presented, the first order of a demand shock is to reduce short-term by more than long-term investments. A demand shock means that consumers want to consume less now and save for the future instead. The increased demand for savings reduces interest rates. Firms will also invest less because demand is lower, but falling interest rates also reduce the opportunity cost of investment in general. The presence of the (temporary) demand shock provides a differential effect depending on the time to payoff of the investment: it is optimal to invest more in long-term investment (which increases output later when the demand shock is over) than short-term investment (which increases output now when demand is low). Overall, long-term investment should then fall less than short-term investment (or even increase), which is the opposite of what we find if credit-constrained firms are also hit harder by the recession. ${ }^{22}$

\section{B. Differential Impact of Uncertainty}

In theory, it is possible that demand shocks could decrease long-term by more than short-term investments. One explanation involves uncertainty; Bernanke (1983) argues that uncertainty increases during a recession, which decreases investment. If uncertainty about expected returns on longrun investments increases by more than uncertainty about expected returns on short-run investments, we might expect to see a differential effect in line with our results-a fall in long-term investments during the recent recession. Also, some empirical evidence in the literature points out

\footnotetext{
22 In the online appendix, we show this formally.
} 
that certain investment types exhibit a cyclical behavior. For example, R\&D has been found to be procyclical (see Barlevy, 2007).

We do not believe that a differential impact of the recession on different investment types is driving the results, because our triple-differences specifications allow us to include category-year fixed effects (which is impossible in the simple difference-in-differences analysis as it is collinear with the interaction term) to control for recession-driven changes in the composition of long- and short-term investments, and our results are robust to this inclusion. For example, the estimates in columns 2 and 3 of the tripledifferences regressions using firm ownership to indicate credit constraints in table 5 are almost identical, and also the robustness checks in table 6 include category-year fixed effects. We would miss this channel only if the differential increase in uncertainty across investment types was different for treated and untreated firms. While this might theoretically be possible for domestic versus foreign firms (e.g., because they are different in size and are exposed differently to foreign markets), the robustness checks indicate that this is unlikely to drive our results. For example, our propensity score reweighting regression in column 3 in table 6 compares only firms of the same size and with the same exporting behavior. Also, columns 4 and 5 control directly for size or productivity differences, and the results are stable. Furthermore, the triple-differences regressions in table 8 use short-term credit just before the financial crisis as an indicator for credit constraints. It is hard to imagine how this measure could be correlated with differential recession-driven exposure to uncertainty about expected returns on different investment types, so we are assured that this hypothesis can be ruled out.

\section{Differential Depreciation}

An alternative argument for why demand shocks could reduce long-term investments by more than short-term investments involves the following reasoning. ${ }^{23}$ In a recession, the negative aggregate demand shock will lead capital stocks to change by the same percentage, but because of the different depreciation rates, this translates into a different percentage change in long-term and short-term investments. However, if we normalize the change in investment by capital stock (instead of investment, which yielded a percentage change), we should not expect to see a differential effect. If (even firm-specific) demand (or productivity) shocks are driving the results, they are netted out across investment types. In columns 3 and 4 of table 2 , we normalize investment by capital stock. We find that a significant negative effect remains. This suggests that aggregate or firm-specific demand or productivity shocks do not fully drive our results.

23 We are grateful to an anonymous referee for providing this argument. The formal model is provided in the online appendix.
In general, we would not expect to see a differential effect of the crisis on long-term investments only for more creditconstrained firms, unless our measures for credit constraints (i.e. foreign ownership and share of short-term debt just before the crisis) are correlated with a larger exposure to the demand shocks. Such correlation may exist for our measure of foreign ownership (which might be correlated with export behavior and therefore differential exposure to other markets), but our matching estimates control for exporting and size and therefore compare companies with similar exposure to demand shocks. Our measure of short-term credit is driven by debt maturity, which seems unlikely to be correlated with different exposure to demand shocks.

In any case, a negative demand shock should be reflected in the output of the firms. So in table 9, we compare the output of credit-constrained firms to the output of unconstrained firms. ${ }^{24}$ The results are in line with our claim. Column 1 shows that more credit-constrained firms (panel A measures credit constraints by ownership, panel B by the share of short-term credit) reduce total investment by more than unconstrained firms. Column 2 reflects our earlier results and shows that credit-constrained firms reduce long-term investments by even more (using the share of the two investment types with the highest durability: machinery and furniture) in total investment as a measure of long-term investment-a cruder measure of the one we used before. However, there is no differential impact on sales: column 3 uses the log of total sales as the dependent variable, which has a small negative but statistically insignificant coefficient. ${ }^{25}$ Debt maturity is arguably more uncorrelated with firms' exposure to demand shock, and the coefficient is smaller and has smaller standard errors.

Besides sales, there is also no differential effect on exports in column 4 or the propensity to export in column 5 of table 9. There is also no sign of a differential creditworthiness or quality of the firms, as both pay the same credit cost, as shown in column $6 .{ }^{26}$ There is also no significant difference in the underlying productivity of firms, as measured by TFP in column 7 .

Alternatively, we can use firm-level sales directly as a measure for each firm's demand shock to see whether it drives the investment patterns in the data. This is done in column 4 of table 6 , where we add an interaction term of the time-to-payoff measure with firm sales. The coefficient on this interaction is negative, which actually goes against the alternative explanation presented above. A negative demand shock would reduce short-term investment by

\footnotetext{
${ }^{24}$ Total investment is the sum of investment over the six investment types: advertising, IT, R\&D, vehicles, machinery, and furniture/office equipment.

25 While this means that we cannot reject that firms with more short-term credit face the same demand shocks, we also cannot reject that they face a slightly larger negative demand shock. In the online appendix, we show that even if we take the coefficient seriously, its magnitude is too small to explain the effect of the recession.

${ }^{26}$ Note that the magnitudes of the coefficients are very small; for example, the coefficient of 0.096 would mean that Spanish firms after the crisis pay $0.09 \%$ higher credit cost, but it is insignificant.
} 
TABle 9.-Robustness Checks: Demand SHOCK

\begin{tabular}{|c|c|c|c|c|c|c|c|}
\hline & $\begin{array}{c}(1) \\
\ln (\text { inv })\end{array}$ & $\begin{array}{c}(2) \\
\text { Long-Term } \\
\text { Inv/Inv }\end{array}$ & $\begin{array}{c}(3) \\
\ln (\text { sales })\end{array}$ & $\begin{array}{c}(4) \\
\ln (\text { exports) }\end{array}$ & $\begin{array}{c}(5) \\
\text { Export } \\
\text { Dummy }\end{array}$ & $\begin{array}{c}(6) \\
\text { Credit } \\
\text { Cost, \% }\end{array}$ & $\begin{array}{c}(7) \\
\ln (\mathrm{TFP})\end{array}$ \\
\hline \multicolumn{8}{|l|}{ A. Spanish firms } \\
\hline$($ Spanish firms $) \times$ & $-0.147^{* *}$ & $-0.065^{* * *}$ & -0.032 & -0.027 & 0.001 & 0.096 & -0.031 \\
\hline (after 2008) & $(0.068)$ & $(0.013)$ & $(0.029)$ & $(0.059)$ & $(0.011)$ & $(0.188)$ & $(0.026)$ \\
\hline Observations & 12,990 & 12,990 & 14,414 & 9,064 & 14,414 & 3,584 & 13,001 \\
\hline Partial $R^{2}$ & 0.001 & 0.002 & 0.000 & 0.000 & 0.001 & 0.004 & 0.000 \\
\hline Number of firm FEs & 2,549 & 2,549 & 2,710 & 1,763 & 2,710 & 1,002 & 2,340 \\
\hline \multicolumn{8}{|c|}{ B. Short-term credit before crisis } \\
\hline (Short-term credit & $-0.108^{*}$ & $-0.038^{* * *}$ & -0.011 & 0.022 & -0.014 & 0.037 & -0.018 \\
\hline dummy) $\times($ after 2008) & $(0.056)$ & $(0.013)$ & $(0.018)$ & $(0.050)$ & $(0.010)$ & $(0.098)$ & $(0.016)$ \\
\hline Observations & 11,429 & 11,429 & 12,608 & 7,964 & 12,851 & 3,131 & 12,050 \\
\hline Partial $R^{2}$ & 0.001 & 0.001 & 0.000 & 0.000 & 0.000 & 0.000 & 0.000 \\
\hline Number of firm FEs & 1,925 & 1,925 & 2,005 & 1,331 & 2,005 & 805 & 1,995 \\
\hline
\end{tabular}

more than long-term investments, which is more in line with another explanation of how demand shocks can differentially affect investment, which we will present below. ${ }^{27}$ What is more, including the interaction term with firm sales does not affect the triple-interaction term with domestic firms (i.e., our regressor measuring credit-constrained firms), suggesting that it is credit constraints rather than demand shocks that drive our results. In column 7 we include interactions with firm-level productivity, but credit constraints as an explanation for the differential investment pattern remain the robust effect.

Thus, overall, we read the evidence as supporting our interpretation that our empirical specifications are indeed measuring the effect of credit constraints, as opposed to demand shocks.

\section{Conclusion}

We have shown how to measure the extent of a credit crunch by analyzing changes in the composition of investment within firms. Intuitively, the extent to which firms are altering the composition of investment away from longer time to payoff toward more immediate payoff is a measure of the risk that the firms perceive of facing liquidation due to lack of access to cash over the relevant period. In this sense, our measure of the credit crunch yields a clearly identified economic parameter, which is readily interpretable. The credit shock is equivalent to an $11 \%$ additional tax on the investment with the longest payoff horizon.

Our findings are particularly important in the specific context of the eurozone credit crisis. This crisis has shown that a credit crunch, previously always thought to affect mainly developing countries, can dramatically affect a developed country - and this in spite of lender-of-last-resort interventions of the central bank, the ECB. Spanish firms affected

${ }^{27}$ Also note that the coefficient on the triple-interaction term with firm sales, time to payoff, and the crisis dummy is very small and insignificant, indicating that a demand shock during the crisis does not affect a firm's investment pattern differently than a demand shock in other years, which it should not. by the credit squeeze cut investments with a medium- to long-term payoff, such as R\&D, innovation, and capital investment, by more than investment with a short-term payoff, such as advertising. Credit constraints force Spanish firms to eat up their future and act as if only the immediate future, tomorrow, mattered. This is likely to have a long-term impact on the Spanish economy, impeding recovery after the financial crisis and reducing long-term economic growth.

Methodologically, our analysis yields estimates of the impact of the crunch that can serve as input for other models. The analysis can be easily extended to other locations, crises, and other capital choices, for example, by comparing changes in the ratio of used versus new capital equipment, which are induced by the financial crisis to measure the cost of the crunch.

\section{REFERENCES}

Adrian, Tobias, Paolo Colla, and Hyun Song Shin, "Which Financial Frictions? Parsing the Evidence from the Financial Crisis of 2007-9" (pp. 159-214), in Daron Acemoglu, Jonathan Parker, and Michael Woodford, eds., NBER Macroeconomics Annual (Chicago: University of Chicago Press, 2012).

Aghion, Philippe, George-Marios Angeletos, Abhijit Banerjee, and Kalina Manova, "Volatility and Growth: Credit Constraints and the Composition of Investment," Journal of Monetary Economics 51 (2009), $1077-1106$.

Almeida, Heitor, Murillo Campello, Bruno Laranjeira, and Scott Weisbenner, "Corporate Debt Maturity and the Real Effects of the 2007 Credit Crisis," Critical Finance Review 1 (2012), 3-58.

Amiti, Mary, and David E. Weinstein, "How Much Do Bank Shocks Affect Investment? Evidence from Matched Bank-Firm Loan Data," NBER working paper 18890 (2013).

Barlevy, Gadi, "On the Cyclicality of Research and Development," American Economics Review 97 (2007), 1131-1164.

Bentolila, Samuel, Marcel Jansen, Gabriel Jiménez, and Sonia Ruano, "When Credit Dries Up: Job Losses in the Great Recession," IZA discussion paper 7807 (2013).

Bernanke, Ben, "Irreversibility, Uncertainty, and Cyclical Investment," Quarterly Journal of Economics 98:1 (1983), 85-106.

Bernanke, Ben, and Mark Gertler, "Agency Costs, Net Worth, and Business Fluctuations," American Economic Review 79:1 (1989), 14-31.

Bernanke, Ben, Mark Gertler, and Simon Gilchrist, "The Financial Accelerator and the Flight to Quality," this REvIEw 78 (1996), 1-15. "The Financial Accelerator in a Quantitative Business Cycle Framework" (pp. 1341-1393), in J. B. Taylor and M. Woodford eds., Handbook of Macroeconomics (Amsterdam: North-Holland, 1999). 
Bernstein, Jeffrey, I., and Theofanis P. Mamuneas, "R\&D Depreciation, Stocks, User Costs and Productivity Growth for U.S. R\&D Intensive Industries," Structural Change and Economic Dynamics 17 (2006), 70-98.

Bertrand, Marianne, Esther Duflo, and Sendhil Mullainathan, "How Much Should We Trust Differences-in-Differences Estimates?" Quarterly Journal of Economics, 119 (2004), 249-275.

Bloom, Nicholas, "The Impact of Uncertainty Shocks," Econometrica 77 (2009), 623-685.

Bureau of Economic Analysis, "A Satellite Account for Research and Development," Survey of Current Business (1994), 34-71.

Campello, Murillo, John R. Graham, and Campbell R. Harvey, "The Real Effects of Financial Constraints: Evidence from a Financial Crisis,' Journal of Financial Economics 97 (2010), 470-487.

Carpenter, Robert E., Steven M. Fazzari, Bruce C. Petersen, Anil K. Kashyap, and Benjamin M. Friedman, "Inventory Investment, Internal-Finance Fluctuations, and the Business Cycle," Brookings Papers on Economic Activity 1994:2 (1994), 75-138.

Chava, Sudheer, and Amiyatosh Purnanandam, "The Effect of Banking Crisis on Bank-Dependent Borrowers,' Journal of Financial Economics 99 (2011), 116-135.

Cleary, Sean, "The Relationship between Firm Investment and Financial Status," Journal of Finance 54 (1999), 673-692.

Corrado, Carol, Charles Hulten, and Daniel Sichel, "Intangible Capital and U.S. Economic Growth,” Review of Income and Wealth 55 (2009), 661-685.

Desai, Mihir A., C. Fritz Foley, and Kristin J. Forbes, "Financial Constraints and Growth: Multinational and Local Firm Responses to Currency Depreciations," Review of Financial Studies 21 (2008), 2857-2888.

Desai, Mihir A., C. Fritz Foley, and James R. Hines, "A Multinational Perspective on Capital Structure Choice and Internal Capital Markets," Journal of Finance 59 (2004), 2451-2487.

DiNardo, John, Nicole M. Fortin, and Thomas Lemieux, "Labour Market Institutions and the Distribution of Wages, 1973-1992: A Semiparametric Approach,” Econometrica 64 (1996), 1001-1044.

Drechsler, Itamar, Thomas Drechsel, David Marques-Ibanez, and Philipp Schnabl, "Who Borrows from the Lender of Last Resort?" Journal of Finance 71:5 (2016), 1933-1974.

Duchin, Ran, Oguzhan Ozbas, and Berk A. Sensoy, "Costly External Finance, Corporate Investment, and the Subprime Mortgage Credit Crisis," Journal of Financial Economics 97 (2010), 418-435.

Eisfeldt, Andrea L., and Adriano A. Rampini, "New or Used? Investment with Credit Constraints," Journal of Monetary Economics 54 (2007), 2656-2681.

Fazzari, Steven M., Robert Glenn Hubbard, and Bruce C. Petersen, "Financing Constraints and Corporate Investment," Brookings Papers on Economic Activity 19:1 (1988), 141-206.

Gan, Jie, "The Real Effects of Asset Market Bubbles: Loan and Firm-Level Evidence of a Lending Channel,' Review of Financial Studies 20 (2007), 1941-1973.

Hubbard, R. Glenn, Anil K. Kashyap, and Toni M. Whited, "Internal Finance and Firm Investment," Journal of Money, Credit and Banking 27 (1995), 683-701.

Ivashina, Victoria, and David Scharfstein, "Bank Lending during the Financial Crisis of 2008," Journal of Financial Economics 97 (2010), 319-338.

Iyer, Rajkamal, and José-Luis Peydró, "Interbank Contagion at Work: Evidence from a Natural Experiment," Review of Financial Studies 24 (2011), 1337-1377.

Iyer, Rajkamal, José-Luis Peydró, Samuel da-Rocha-Lopes, and Antoinette Schoar, "Interbank Liquidity Crunch and the Firm Credit Crunch: Evidence from the 2007-2009 Crisis," Review of Financial Studies 27 (2014), 347-372.

Jimenez, Gabriel, Atif R. Mian, José-Luis Peydró, and Jesus Saurina, “Local versus Aggregate Lending Channels: The Effects of Securitization on Corporate Credit Supply in Spain," NBER working paper 16595 (2010).

Jimenez, Gabriel, Steven Ongena, José-Luis Peydró, and Jesus Saurina, "Credit Supply and Monetary Policy: Identifying the Bank Balance-Sheet Channel with Loan Applications," American Economic Review 102 (2012), 2301-2326.

Kalemli-Ozcan, Sebnem, Herman Kamil, and Carolina Villegas-Sanchez, "What Hinders Investment in the Aftermath of Financial Crises: Insolvent Firms or Illiquid Banks?" NBER working paper 16528 (2010).

Kaplan, Steven N., and Luigi Zingales, "Do Investment-Cash Flow Sensitivities Provide Useful Measures of Financing Constraints?" Quarterly Journal of Economics 112 (1997), 169-215.

Khwaja, Asim Ijaz, and Atif Mian, "Tracing the Impact of Bank Liquidity Shocks: Evidence from an Emerging Market," American Economic Review 98 (2008), 1413-1442.

Kiyotaki, Nobuhiro, and John Moore, "Credit Cycles," Journal of Political Economy 105 (1997), 211-248.

Klein, Michael, Joe Peek, and Eric Rosengren, "Troubled Banks, Impaired Foreign Direct Investment: The Role of Relative Access to Credit," American Economic Review 92 (2002), 664-682.

Kuppuswamy, Venkat, and Belén Villalonga, "Does Diversification Create Value in the Presence of External Financing Constraints? Evidence from the 2008-2009 Financial Crisis," Management Science 62 (2016), 905-923.

Lamont, Owen, "Cash Flow and Investment: Evidence from Internal Capital Markets," Journal of Finance 52 (1997), 83-109.

Landes, Elisabeth M., and Andrew M. Rosenfield, "The Durability of Advertising Revisited," Journal of Industrial Economics 42 (1994), 263-276.

Mian, Atif, and Amir Sufi, "The Effects of Fiscal Stimulus: Evidence from the 2009 Cash for Clunkers Program," Quarterly Journal of Economics 127 (2012), 1107-1142.

Nadiri, M. Ishaq, and Ingmar Prucha, "Estimation of the Depreciation Rate of Physical and R\&D Capital in the US Manufacturing Sector," Economic Inquiry 34 (1996), 43-56.

Nichols, Austin, “Causal Inference with Observational Data," Stata Journal, 7 (2007), 507-541.

" "Erratum and Discussion of Propensity Score Reweighting," Stata Journal 8 (2008), 532-539.

Pakes, Ariel, and Mark Schankerman, "The Rate Obsolescence of Patents, Research Gestation Lags, and the Private Rate of Return to Research Resources" (pp. 73-88), in Zvi Griliches, ed., R\&D, Patents, and Productivity (Chicago: University of Chicago Press, for the National Bureau of Economic Research, 1984).

"Estimates of the Value of Patent Rights in European Countries during the Post-1950 Period," Economic Journal 96 (1986), 10521076.

Paravisini, Daniel, "Local Bank Financial Constraints and Firm Access to External Finance," Journal of Finance 63 (2008), 2161-2193.

Paravisini, Daniel, Veronica Rappoport, Philipp Schnabl, and Daniel Wolfenzon, "Dissecting the Effect of Credit Supply on Trade: Evidence from Matched Credit-Export Data," Review of Economic Studies 82 (2015), 333-359.

Santos, Joao C., "Bank Corporate Loan Pricing Following the Subprime Crisis," Review of Financial Studies 24 (2011), 1916-1943.

Schnabl, Philipp, "The International Transmission of Bank Liquidity Shocks: Evidence from an Emerging Market," Journal of Finance 67 (2012), 897-932.

Tamai, Tetsuo, and Yohsuke Torimitsu, "Software Lifetime and its Evolution Process over Generations" (pp. 63-69), in Proc. Conference on Software Maintenance (Piscataway, NJ: IEEE, 1992).

Whited, Toni M., "Debt, Liquidity Constraints, and Corporate Investment: Evidence from Panel Data,' Journal of Finance 47 (1992), 14251146. 